\title{
FADS AND FASHIONS IN MANAGEMENT: the case of ERP
}

\author{
Miguel P. Caldas \\ B.A. (UnB), Master and Ph.D. Degrees in Business Administration (EAESP/FGV), Professor \\ of the Management Department at EAESP/FGV, and Management Consultant. \\ E-mail:mcaldas@fgvsp.br \\ Thomaz Wood Jr. \\ B.S. in Chemical Engineering (Unicamp), Master and Ph.D. Degrees in Business \\ Administration (EAESP/FGV), Professor of the Production and Operations Management \\ Department at EAESP/FGV, and Management Consultant. \\ E-mail: twood@fgvsp.br
}

\section{RESUMO}

Este artigo discute a "onda" dos Sistemas Integrados de Gestão (SIG). Os SIG representam imensos investimentos para empresas em todo o mundo e têm sido promovidos como panacéias gerenciais. Previsivelmente, muitas implantações não atendem às expectativas. Neste estudo, propomos uma perspectiva ampla para a compreensão dos fatores substantivos, institucionais e políticos envolvidos no fenômeno SIG, como uma alternativa ao "tecnoreducionismo" que tem caracterizado as abordagens usuais ao tema, e apresentamos uma pesquisa exploratória com 28 experiências de implantação, concentrando o foco no processo de adoção, na abordagem escolhida para implantação e na avaliação dos resultados.

\section{ABSTRACT}

This article discusses the Enterprise Resource Planning (ERP) rage. $E R P$ represents immense investments for companies around the globe and has been promoted as a management panacea. Not surprisingly, many implementations fail to match expectations. In this study, we propose a broader perspective to comprehend the substantive, institutional, and political factors involved in the ERP phenomenon, as an alternative to the "techno-reductionism" that has characterized the prevailing approach on the subject, and present an exploratory survey of 28 implementation experiences, concentrating on the process of adoption, chosen implementation approaches and outcome assessment.

PALAVRAS-CHAVE

Sistema Integrado de Gestão, inovação gerencial, modas e modismos gerenciais.

KEY WORDS

Enterprise Resource Planning, managerial innovation, management fads and fashions. 


\section{ONCE UPON A TIME...}

Once upon a time there was a subsidiary of a European multinational organization in a certain emerging country. We will here name the organization "La Vie en Rose" (LVR). Good profits, dedicated executives, proud employees: LVR had always been a successful organization. Its only problem was a certain fling for management fads. Nothing grave. Every year or so, a novelty was joyfully adopted. First, it was statistical process control. Then, it was total quality. Afterwards, came strategic alliances, and, obviously, reengineering. Nothing too harmful. On the contrary: to surf on management fads tended to impel the career of executives, to give a helping hand to all acquaintances within consulting firms, and, ultimately, to shake up the organization.

However, something unexpected happened, a nightmare that began as a golden dream. As happened with other organizations in the marketplace, LVR dealt with a chronic problem: information fragmentation. With business growth and the increased complexity of their operations, each area in the organization developed its own information systems, investing millions in hardware and software. As a result, LVR witnessed an escalation of investments, systems that did not communicate with each other, and, paradoxically, a significant lack of information for decision making.

And then the perfect solution emerged: Enterprise Resource Planning (ERP) systems. Competitors were adopting it, gurus were all prescribing it, and business media had hardly a word about anything else. LVR simply could not stay out of it. The investment would be monumental, and the implementation would be no rose garden. But, at the end of the day, the entire organization would be completely integrated in one single system. It would only take a consumer pulling a LVR product out of a supermarket shelf to trigger a complex web of system connections, which would command inventory supply, invoices, production planning, supplier ordering, and so on. The new system would improve information, speed up decision making, reduce costs, and multiply net profits. A true finding!

Nevertheless, in practice theory worked differently, and LVR's golden dream soon turned into nightmare. First came all sorts of implementation difficulties: inexperienced consultants, unprepared users, chronic delays, and significant budget overruns. Then the organization realized that its main business processes would not fit the new system: the organization had to be adapted to the system's needs. And even worse: after twelve months of concentrated energy spent on the implementation effort, important decisions were being delayed, clients were beginning to complain, and shareholders were becoming impatient.

Although many organizations that are implementing ERP systems are indeed reporting a great deal of gain and success, the nightmare that stroke LVR is becoming more frequent everyday. The uneasiness around ERP seems to grow hand in hand with the astonishing escalation of its implementation market. But, despite the importance of the subject, it has received little attention in academic management journals.
There seems to be no doubt that the effective management of information in an organization can today be a source of competitive advantage. But not all the examples are so clear, and the potential relationship between information technology and competitive advantage in most organizations is difficult to be determined.
The objective of this study is to discuss the ERP phenomenon from a non-reductionist viewpoint, one that would comprise its contextual, institutional, and political dimensions. The selected strategy was to combine theory and practice, through an exploratory, empirical survey. From such interaction we will propose a broad, non-reductionist perspective covering conceptual propositions and elements that may be useful to the comprehension of the ERP phenomenon.

The article is structured as follows:

- section two presents a brief introduction to the ERP phenomenon, and attempts to explain the frantic diffusion of ERP in business nowadays;

- section three summarizes methods and results of an exploratory field survey involving 28 cases of ERP implementation;

- section four summarizes a broader, alternative, perspective on the phenomenon of ERP systems diffusion, strongly based on the results of the exploratory survey and on the literature covering the diffusion of management innovations;

- section five crosses the multidimensional perspective proposed and the findings of the exploratory field survey, to generate three series of 
issues which should be further investigated in future studies;

- section six presents a synthesis of the article and indicates directions for future research.

\section{A BRIEF INTRODUCTION TO THE WONDERFUL WORLD OF ERP}

There seems to be no doubt that the effective management of information in an organization can today be a source of competitive advantage. In fact, organizations such as American Airlines, Federal Express and Amazon Books owe part of their success to the intelligent use of information. But not all the examples are so clear, and the potential relationship between information technology and competitive advantage in most organizations is difficult to be determined. According to some specialists (e.g., McGee, Pyburn and Pruzak, 1993), extensive investments in information technology have failed to produce all of its transformation potential, nor have they generated significant financial returns.

The idea that complex problems can be rapidly resolved by investing in sophisticated machinery is quite seductive. However, at the heart of such notion lies an almost irrational belief that technology in general and information technology particularly will provide a cure for all evils.

More recently, ERP systems have become in fact a fixed idea for managers and entrepreneurs. Executives devote to them endless hours and attention. Their attributes bring about futuristic fantasies. Business media dedicate to them cover pages and in-depth special reports. Users publicize their virtues and show off the millions the implementations they lead saved for their organizations. Ultimately, ERP systems seem to have simply conquered hearts and minds throughout the business realm.

Naturally, this turmoil was accompanied by the formation of a significant market for ERP vendors and service providers. In 1997, the market for software vendors alone was estimated in US\$ 10 billion. Another US\$ 20 billion in business were calculated in management consulting and supplementary software, and up to US\$ 10 billion in hardware and accessories (SAP..., 1998). As shown in Exhibit 1, by the end of 1998, software vendors alone were forecasting annual sales of more than US\$ 15 billion. SAP, the market leader, is the fastest growing software company in the world (Davenport, 1998). More recently, specialists forecasted the entire enterprise software market to grow up to US $\$ 70$ billion by the end of 2002 (AMR, 1998).

The expectations of ERP's impact on organizations are enormous, as well as the sum of investments involved. The implementation budget for mediumsized organizations such LVR can run up to US\$ 20 million, and a few multinational conglomerates have announced investments of almost US\$ 500 million (Davenport, 1998).

ERP systems can be implemented, with adjustments, in any organization. Economies of scale can bring an

Exhibit 1 - Top ERP vendors by total projected company revenue (1998)

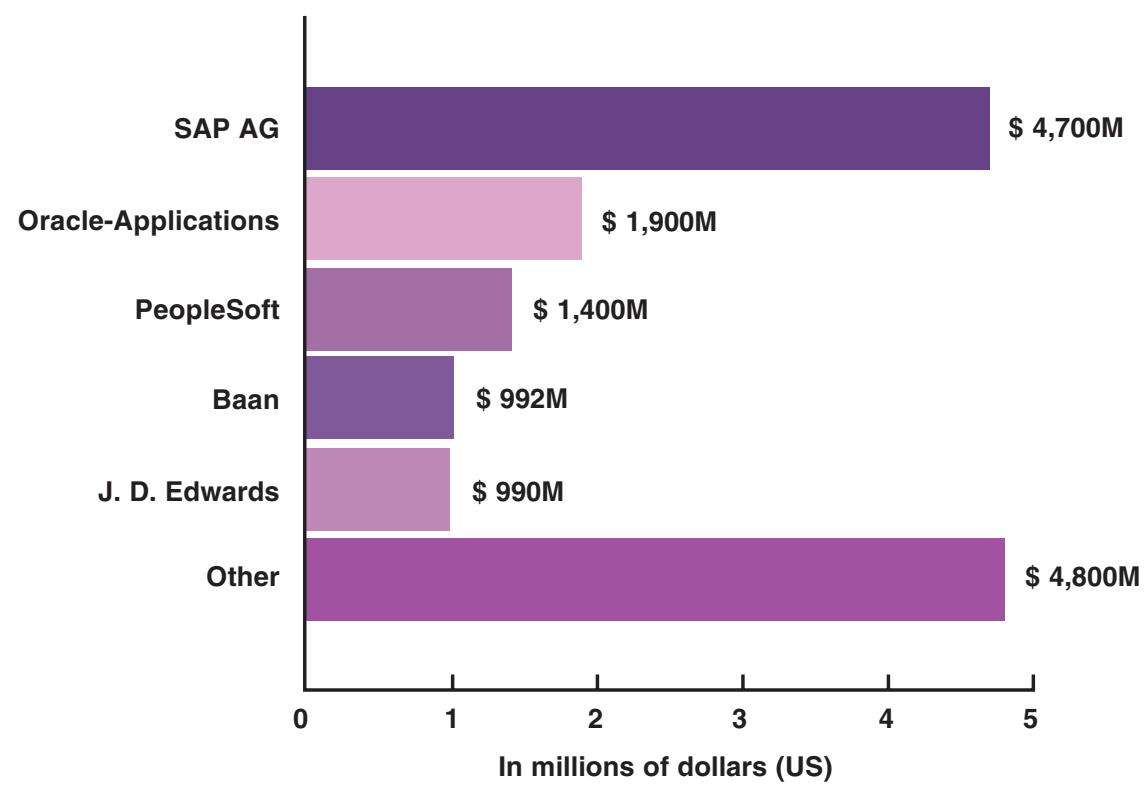

Source: AMR (1998). 
important cost advantage for solutions tailored for each company. Such systems are capable - or so it is said of integrating the management of the entire organization, by speeding up decision making. And they may also allow organizational performance to be monitored in real time.

But, overall, ERP implementations involve, in truth, broad organizational transformation processes, with significant implications on the organization's management model, organization structure, management style and culture, and, particularly, on people. Such implementations generally constitute immense projects, which seldom take less than 18 months, and which mobilize large multidisciplinary, dedicated teams, comprised normally of information technology specialists, key users and operations personnel, as well as consultants with process redesign and change management skills.

Unfortunately, many executives and consultants still have not realized the breadth and the significance of the organizational impacts that such implications can raise. Much of what is reported and written in the business media on the subject is known to be, at best, wishful thinking. In the meantime, a few consultants and academics (e.g., Davenport, 1998; Correa, 1998) are beginning to disrupt a certain misinformed unanimity that has been created around the subject, and some have even ventured to make a discouraging prognosis about the future of such systems (Carvalho, 1998). But fantasies and overreactions aside, the truth is that ERP is at the top of today's agenda, and that the total investments involved are astronomical.

A central problem in this matter is that decisions regarding the implementation of such systems have been made in an atmosphere of great urgency, created by both the promotional strength of vendors, and the political agenda of executives within organizations (Lampel, 1995). Options end up limited to the leading software vendors (SAP, PeopleSoft, Baan, etc.), on one hand, and to the largest consulting firms, on another. And, ultimately, many organizations are allocating a lot of time, money and energy in poorly elaborated projects.

Those who make it to the end of this marathon tend to celebrate, but truly without guaranties that it was either worth it, or that the professed benefits will at length justify the high price that the process has entailed.

\section{THE EXPLORATORY FIELD SURVEY}

In this section we shall summarize the methodology and main findings of an exploratory field survey involving ERP implementations.

\section{Research design and methodology}

The field survey involved the investigation of ERP implementation processes in 40 organizations. Trained researchers conducted, from August through November of 1998, 107 interviews in these 40 companies. The scope of the investigation was limited to the operations of each organization in the emerging economy where the interviews took place.

\section{The idea that complex problems can be rapidly resolved} by investing in sophisticated machinery is quite seductive. However, at the heart of such notion lies an almost irrational belief that technology in general and information technology particularly will provide a cure for all evils.

The (non-randomic) sample included organizations from a large array of industries: pharmaceutical, chemical, textile, telecommunications, automotive, consumer goods, electronics, financial, and so on. Most of the organizations were large or mid-sized. A significant proportion (85\%) was comprised of subsidiaries of foreign multinational corporations, which could benefit from the previous experience of the implementations conducted by their home operations.

The initial sample was filtered using a validation protocol, resulting in 28 valid organizations and 56 usable interviews. For the purposes of this study, the filtering process excluded (i) firms that were still going through the implementation phase; (ii) firms where only one interview was obtained; (iii) interviews with an entire category of respondents (consultants), whose sample was insufficient; and (iv) incomplete interviews.

As a result, all organizations in the final sample had implemented an ERP system. Most of them, at the time the survey was conducted, had completed the initial roll-outs, and were in the process of expanding the implementation in terms of scope (new functionalities), and breadth (other business units or sites).

The interview script used in the field survey was developed using the multidimensional perspective outlined in the previous section. It contained 55 questions -7 multiple-choice questions, 45 Likert- 
scaled questions, and 3 opened questions - and was divided in five segments: (1) firm and respondent identification; (2) reasons to implement ERP; (3) implementation approach; (4) implementation results; and (5) implementation assessment.

In the final sample, each question was answered by two people in the organization: one had to be an implementation agent (an employee of the organization who had coordinated or intensively participated in the ERP implementation), and the other had to be a key user (i.e., an employee of the organization that made significant use of the ERP system).

All responses were then classified and analyzed. The following subsection presents a summary of the major findings.

\section{Findings}

\section{Reasons to implement ERP}

The main reason to implement the ERP system was the "need to integrate the organization's processes and information", a substantive reason. The other leading answers were "the need to follow a trend" (an institutional reason), followed by "the need to meet the pressures of the IT function", and "the pressures of the head office" (both political reasons).

Exhibit 2 shows the main reasons cited in the sample. Percentages refer to the number of respondents that pointed out each element as a relevant factor during implementation decision.

Concerning this topic, it is remarkably high $(36 \%)$ the percentage of respondents that declared that "the firm didn't know exactly what it was buying" or "what could be expected from the System".

\section{The implementation approach and focus}

Results suggest, from the viewpoint of the respondents, that several distinct practices exist in terms of the implementation method: whereas $44 \%$ stated that it was consensual, $41 \%$ of the respondents cited that it was imposed. In either case, $30 \%$ of the respondents said that user involvement was low or insufficient.

Similar diversity can be observed regarding the implementation approach: $24 \%$ affirmed that the process was focused on its human side and in its transformational aspects, whereas $36 \%$ admitted that the process was more heavily focused on technology.

In most companies (71\%), implementation followed reengineering, or was conducted simultaneously with reengineering. On the other hand, only $34 \%$ of respondents declared that the reengineering process was conducted in depth.

The use of external support was also surveyed: $91 \%$ of the implementation processes were conducted using assistance of management consultants. However, only $47 \%$ of all respondents claimed that the consulting firm was operative and influential during the implementation process, and no more than $23 \%$ cited that the consultants had the necessary skills and experience.

\section{The implications}

The overall perception of the respondents in the sample is that the implementation generated significant improvements to their organization. However, one cannot mention unanimity, and when analyzing specific issues, it is possible to verify significant levels of frustration. For example: $45 \%$ of the respondents did not perceive any improvements whatsoever in terms of competitive advantage; $43 \%$ affirmed that no cycle time reductions were obtained; and $40 \%$ admitted that there were no gains in customer service.

Moreover, several negative effects were cited in moderately significant percentages - between $5 \%$ and $15 \%$ -, particularly relating to issues such as flexibility and costs.

Exhibit 2 - Why firms in the sample implemented ERP

\begin{tabular}{|c|c|c|}
\hline Reasons to implement ERP & $(\%)$ & Type of reason \\
\hline - Integration of processes; integration of information & 91 & Substantive \\
\hline - Follow trend & 77 & Institutional \\
\hline - Pressures from the IT function & 41 & Political \\
\hline - Pressures from the head office & 41 & Political \\
\hline - Avoid giving up space to competitors & 37 & Substantive \\
\hline - Internal political reasons & 31 & Political \\
\hline - Media influence & 29 & Institutional \\
\hline - Influence of management gurus and consultants & 23 & Institutional \\
\hline - Pressure from clients and/or suppliers & 11 & Substantive/Institutional \\
\hline
\end{tabular}


The main advantages quoted in the open questions were: increased integration amid areas and sites; increased information integration, and process integration; improvement on the quality of information; favorable opportunity to rethink processes; and improved level of control.

As to the disadvantages cited in the open questions, the most significant are: ERP system failed to tailor itself to the specific needs of the organization; loss of key organizational functions, due to system requirements; superficial process redesign; high dependency of a single software provider; and excessive control.

To many respondents, the implementation was a painstaking job, usually characterized by scope and planning mistakes. Of all respondents, $91 \%$ agreed that, if given the opportunity to decide again, the organization would once more chose to implement the ERP system. However, $25 \%$ of them said they would significantly change the scope and/or the implementation approach.

\section{TRYING TO MAKE SOME SENSE OUT OF THE ERP CRAZE: PROPOSING A NON-REDUCTIONIST PERSPECTIVE}

We believe that the practice of management associated with ERP implementation efforts can largely benefit from the utilization of a broader perspective to its comprehension, one that could challenge the reductionism and information technology biases that have characterized the prevailing approach on the subject. In the remaining of this section, strongly based on the results of the exploratory survey summarized above and on the literature covering the diffusion of management innovations, we will propose one such broader, alternative, perspective on the phenomenon of ERP systems diffusion.

The perspective we pose arises from the confluence of three sets of factors: substantive factors, institutional factors, and political factors. As shown on Exhibit 3, all these factors interact with each other, creating a complex dynamic process. All three, alone and in combination, at the end influence (i) the adoption, (ii) the implementation approach, and (iii) the assessment of ERP systems in organizations.

\section{Substantive factors}

Substantive factors comprise all real imperatives, problems or opportunities that organizations face and for which ERP systems are an adequate and effective response. They are generally mentioned in most of the technical literature, or in brochures of management consulting firms, and include drivers and enablers which impel the actual need for information integration.

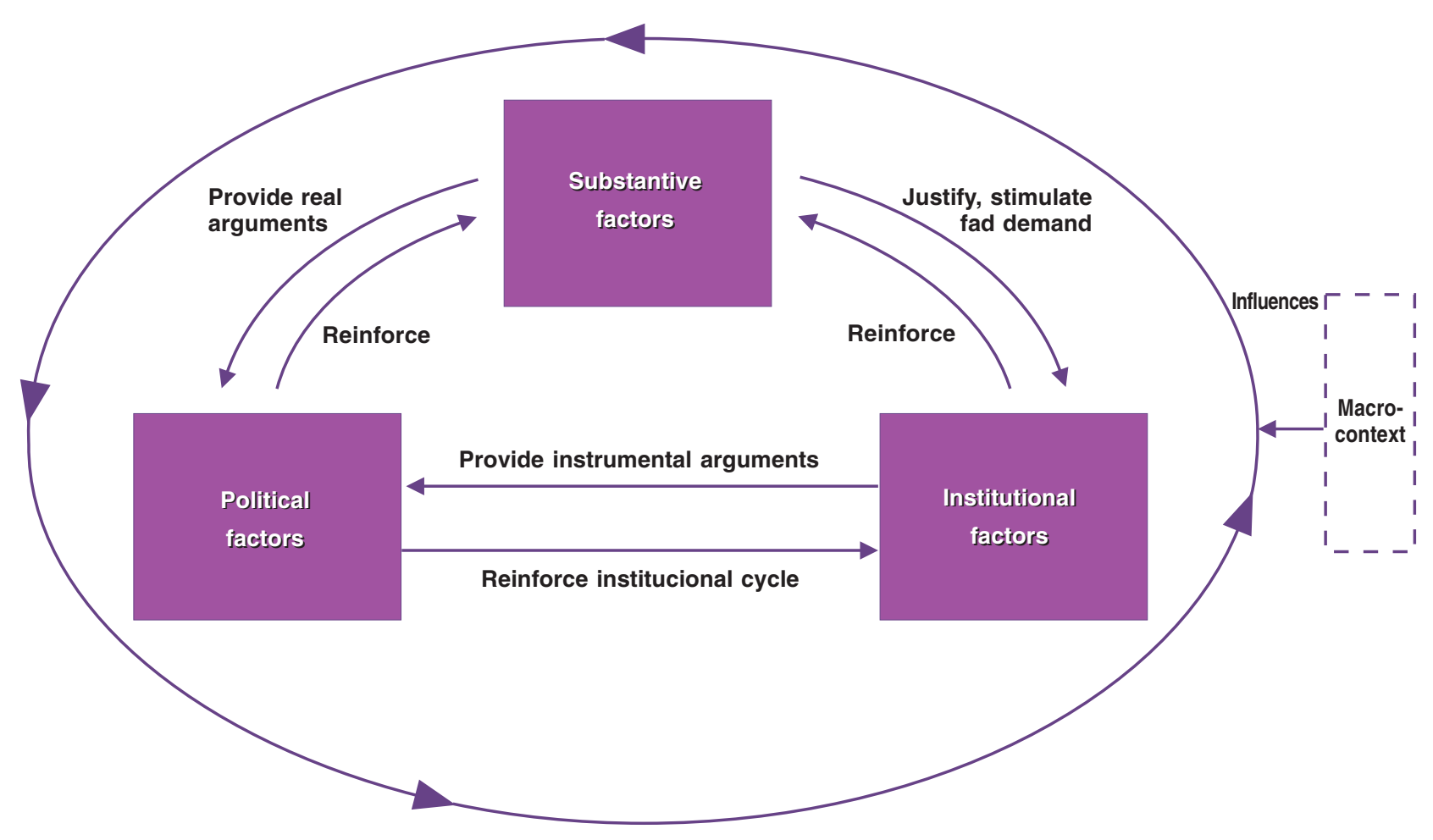


Among them, one may list:

- growing need to integrate the operations of multinational conglomerates: this first driver makes the coherent integration and treatment of information a mandatory requirement; after all, in most markets nowadays, multinational organizations are striving to integrate their global operations. Such integration is perceived as necessary for at least two sets of reasons - firstly, because by integrating their operations they can rapidly diffuse innovations globally, deploy international best practices, and further leverage their scale and global competitive advantage; and, secondly, because by integrating their information systems, they believe they can more efficiently manage and control key investments, strategic resources, as well as main decisions across borders;

- constant pressure to reduce costs and improve efficiency: this driver also demands a high level of information integration. Such integration would allow systemic improvements, which would result in shorter customer service and fulfillment cycles, reduction of logistical costs, inventory cutback, and so on. Other examples of this type of latent integration opportunity include: reduction of headcount and inventory, standardization of process design and of hardware/software configurations, minimization of systems integration costs and IT personnel, as well as a reduction on the use and expense with materials;

- significant trend toward the adoption of processbased management models: for the past few years, it seems undeniable that process-based structures and models have deeply influenced organizations all over Western organizations, before and beyond the reengineering fad. However, a typical barrier to the thorough implementation of this more horizontal perspective has been the difficulty to integrate information and information systems across the organization. Hence, ERP meets the primary requirement of most primary management models and operational templates that are in use today, sharing their same process-based perspective on work design;

- emergence of information technology architectures that make integration possible: this second enabler granted the technological basis, including client-server architectures and datasharing technology, that provided the means to the existence of modern ERP systems.

\section{Institutional factors}

Institutional factors comprise all external forces existing in the organizational environment, which pressure the adoption of ERP systems. Institutional factors are commonly discussed in the literature on management fads and fashions. Such literature analyzes how fads are created and tend to generate cycles of management panaceas (Gill and Whittle, 1992), their patterns of diffusion and rejection in organizations (Abrahamson and Fairchild, 1997; Caldas, 1996; Caldas and Wood Jr., 1995) and reasons for adoption of new managerial technology in organizations (Abrahamson, 1991, 1996). Viewed from this standpoint, ERP systems can be perceived as successors of other management panaceas as TQM, downsizing and reengineering. The most significant institutional factors can be divided as: - interests of primary diffusion agents: primary diffusion agents are those involved in the creation of new management technologies and fads, and that survive directly and almost exclusively of the revenues generated by their diffusion. In the case of ERP systems, such agents naturally include vendors of ERP hardware and software, as well as consulting firms seeking the significant potential business generated by pre-implementation, implementation, and post-implementation challenges faced by their clients. Regarding the former, an obvious interest in the ERP craze is that of the many software and hardware vendors involved in the selling of its implementation and of its add-ons. During implementation, a large portion of the huge investments already mentioned goes to vendors, which has caused ERP-related business to become a multi-billion dollar market in just a few years. But the initial investment is but a piece of the vendors' interest. What many organizations are finding out nowadays is that, firstly, ERP demands state-of-the-art hardware, which on its turn demands constant updates; and, secondly, that many of the key capabilities it allows us to envision are not immediately at hand, but they are most certainly due in the software's next releases! Obviously, for a price. Hence, ERP's endless need for updates and upgrades makes it a fine continuous business for those that supply technology to ERP-based organizations. Concerning the latter, certified consulting firms are obvious interested parties within the ERP craze. Although such firms also take in a large part of the risk - smartly avoided by some of the software vendors -, they get large assignments, which have, on their turn, transformed the big leagues within the consulting industry. Therefore, when accounting for the instrumental interests sponsoring ERP in organizations nowadays, one has to remember that large consulting firms are after the pre-implementation (BPR, systems planning), implementation (parametring, 
systems integration, change management), and postimplementation (organization redesign, organizational transformation and development, etc.) consulting fees;

- interests of secondary diffusion agents: secondary agents are those that live in the edge of the market created by management fads, and include individuals and organizations that profit indirectly from their diffusion. In the case of ERP systems, such agents include: (a) technical and business media, which tends to have a significant interest by the business that the ERP issue can produce; (b) management gurus and business books publishers, for whom ERP defines an attractively growing market niche; and (c) business schools, training organizations and seminar promoters, which nourish the escalating demand for technical instruction and information on ERP systems.

The combined influence of these two types of diffusion agents generates a strong isomorphic pressure, that pushes each organization to comply to institutionalized (i.e., socially legitimated) management practices. A good deal of the so-called neoinstitutional literature (e.g., Meyer and Rowan, 1977; DiMaggio and Powell, 1983; Scott, 1987) has attempted to explain why organizational practices - as is the case nowadays with ERP - may end up as a standard practice within vast "institutional fields", be it by its imposition (coercive isomorphism), by its social legitimization (normative isomorphism), or by imitation (mimetic isomorphism).

\section{Political factors}

At last, political factors reflect the interests of power groups and coalitions inside the organization. They relate to those organizational needs for which ERP systems do not pose direct solutions, but for which ERP systems are ideal means to obtain a solution, or yet its associated outcome. Despite its great relevance, political factors are seldom mentioned in the literature on managerial innovations (e.g., Frost and Egri, 1991), let alone on ERP systems (e.g., Brown, 1998; Davenport, 1998). Typically, the most significant political factors are:

- centralization interests: ERP systems may be used by the strategic apex (i.e., top management), or by managers connected to corporate functions, to centralize decision making and to increase control over subsidiaries or business units (Mintzberg, 1983);

- standardization and concentration interests: managers at corporate areas and functions can take advantage of ERP systems to enforce the standardization of processes and operations - and potentially their concentration as shared staff functions - that otherwise would remain autonomously designed at the subsidiary or business unit level;
- interest of power groups and coalitions: as mentioned before, the implementation of an ERP system may result in profound changes in work design, organizational structure and internal power configuration. Hence, an ERP implementation may become an arena in which several groups battle seeking not only to control the project - an obvious source of power and influence -, but also to expand their authority and influence amid the turbulence that the transformation will probably bring about;

- IT departments' quest to regain power: the Information Technology function gave in quite a lot of ground in organizations in the last decade, due to the system decentralization (which followed technological downsizing) and outsourcing movements. ERP systems can certainly represent an opportunity for such departments to regain lost authority and influence.

Altogether, as suggested in Exhibit 3, those factors substantive, institutional, and political - are closely connected.

Substantive factors - generally influenced by contextual conditions - influence both institutional and political factors. On one hand, they generate the demand for solutions (production of innovations) activating institutional factors, and, on the other, they provide the concrete arguments to validate internal justification (political factors) within organizations.

Institutional factors also influence political and substantive factors. Such influence occurs, firstly, because institutional factors provide legitimized vehicles to justify political factors, granting interest groups with a management technique they can take advantage of in their own benefit; and, secondly, because institutional factors end up reinforcing most substantive factors, by giving them an image of particular urgency and relevance.

And, lastly, political factors also influence substantive and institutional factors. They influence all substantive factors by giving them a sense of propriety and sufficiency, which was attributed to ERP by internal groups in their own behalf. And they also reinforce institutional factors, by nurturing diffusion agents that will serve the purposes of power groups within the organization, and by reinforcing the idea of inevitability of the ERP adoption trend.

One of the main arguments in this study is precisely that, whereas the current reductionist discourse on ERP systems concentrates solely on substantive factors, the ERP phenomenon can only be fully understood if it is also perceived in terms of the institutional and political factors which concur to define it, within and around the organization. 


\section{DISCUSSION}

From the interaction between the multidimensional perspective proposed on the previous section and the findings of the exploratory field survey (section three), a series of issues should be raised, which could be further investigated in future studies. Such issues refer to (i) the context of adoption of ERP as a management solution, (ii) the approach given to the implementation effort, and (iii) the assessment of the outcomes of the implementation. Each one is briefly discussed below.

\section{The context of adoption}

The first issue concerns the context and mechanisms that pervade decisions of ERP adoption. The outcomes of the field survey revealed an ensemble of substantive, institutional and political factors. Additionally, a high percentage of respondents recognized that "the firm didn't know exactly what it was buying" nor "what could be expected from the System".

These types of outcomes are similar to conditions commonly associated with the adoption of managerial fads and fashions: high level of emotional content during the adoption decision, and a certain degree of euphoria during implementation. The scarcity of rationality in the decision process may be related to the institutional pressure for adoption, or yet to the lack of know-how for a detailed analysis. In such cases, the result tends to be projects poorly elaborated and a high degree of frustration during and after implementation.

\section{Implementation approach}

The second issue concerns the approach by which ERP has been implemented. The field survey revealed a remarkable diversity in terms of perspectives. Many organizations may have failed because they perceived their ERP implementation merely as another information technology (IT) project, and not as a major organizational transformation as they should have. One could suppose that part of the reason for such a limited approach derives from the pressures for adoption coming from IT personnel.

The field survey also revealed that some organizations seemed to adopt an expanded approach, i.e., one that considers the ERP implementation as some type of "IT-meets-reengineering-project". However, it should also be mentioned that a significant part of respondents considered the process reengineering that their ERP implementation contained as quite superficial.

When they did not realize the great impact ERP implementation would have on people and management, several organizations not only failed to generate the gains of a deeper organizational transformation, but they also have put themselves at risk, by ignoring the interactions between ERP and other organizational dimensions and variables. During such interventions, the more one restricts the implementation approach, the more pernicious one may expect the side effects to be in the organization as a whole.

\section{Outcomes of the implementation}

The third issue concerns the outcomes of the implementation. To an external observer, the survey's findings may be disappointing. Remarkably, the low impact of the ERP implementation on items such as competitive differentiation and costs denounces the existence of serious problems in many implementations.

Also noteworthy are some disadvantages pointed by respondents such as low fit between the system and specific business needs, which may lead to the loss of some strategic functions and information, as has been predicted by theorists before (e.g., Davenport, 1998).

Paradoxically, most of the respondents in the survey seem to agree that there is no alternative to the ERP trend, and that the outcomes are mainly positive. Although it seems undeniable that for many organizations a successful ERP implementation has indeed solved substantive problems and/or operational deficiencies, the survey also reveals flaws in this type of not-necessarily-grounded-consensus. It is precisely here that it seems appropriate to point out the politicalinstitutional context that surrounds ERP implementations. If we combine, on one hand, the strong political and institutional drivers discussed on section four, and on the other, the immense investments involved and the high hopes concerning the outcomes of the ERP project, one may expect it all to significantly impair a critical assessment. In fact, one could state that there are many stimuli to "lipservice" (i.e., ceremonial) behavior (Caldas and Wood Jr., 1997). Thus, even when results may be deceiving, assessments could remain mostly positive.

\section{CONCLUSIONS}

In this section we will briefly present a synthesis of the article and suggestions for future research.

\section{Synthesis}

In this article we examined the ERP phenomenon. We argued that ERP should be understood as a complex phenomenon. A broader perspective that considered its 
substantive, institutional, and political factors was proposed, as an alternative to the (technological) reductionism that has characterized the prevailing approach on the subject. The ERP diffusion, which is occurring at an extremely accelerated pace, has been supported by a fierce promotional apparatus and institutional momentum. The article suggests, based on the exploratory survey, that such environment may inhibit reflection and be characterized by low levels of critical posture. The outcome is the proliferation of failures in implementation, growing dissatisfaction and some degree of "lip-service" (i.e., ceremonial) behavior, while a few, more comprehensive and transformational approaches to the ERP implementation do have better chances to succeed.

In order to support our analysis, we conducted an exploratory field survey involving 28 organizations that have implemented ERP. The survey unveiled, among other things, the following findings: (i) adoption processes were strongly influenced by institutional and political factors, reproducing conditions usually related in the literature to the adoption of managerial fads and fashions; (ii) implementation is frequently guided by an oversimplified (naive) approach, potentially resulting in undesirable side effects; and (iii) outcomes are deceiving, especially if one considers the large investments involved and the frenzy that surrounds it.

\section{Future research}

We consider this article an initial, exploratory effort. We believe that the theme of ERP adoption and implementation should receive further attention by academics and practitioners.

A first alternative for future research could consider longitudinal studies of firms that implemented ERP. Most of the implementations are, for the moment, quite recent. A longitudinal study could evaluate, more properly, implications and outcomes of ERP implementation over time.

A second alternative would be to investigate in depth the influence of each set of factors here presented (substantive, institutional, and political) over the three major steps of an ERP implementation: the process of adoption, the implementation approach and the assessment of outcomes.

A third alternative would be to develop criteria to identify successful implementations, seeking to understand which set of decisions may foster success and which may restrain it.

And, lastly, we believe that this stream of research could benefit also from qualitative and/or ethnographic methodologies, which could focus more properly on the interaction among internal interest groups, the organization, as well as external agents during the implementation of ERP. $O$

\section{REFERENCES}

ABRAHAMSON, E. Managerial fads and fashions: the diffusion and rejection of innovations. Academy of Management Review, v. 16, n. 3, p. 586-612, July 1991.

ABRAHAMSON, E. Management fashion. Academy of Management Review, v. 21, n.1, p. 254-285, Jan. 1996.

ABRAHAMSON, E., FAIRCHILD, G. Management fashion: lifecycles, triggers, and collective learning processes. Pape presented during the Annual Meetings of the Academy of Management. Boston, MA: Academy of Management, Aug. 1997

AMR research predicts industrial enterprise applications market will reach $\$ 72.6$ billion by 2002. Boston, MA : AMR Research, Nov. 2, 1998. Press Release. Also in No stopping ERP. PCWeek. [cited 1998-11-30]. Available from Internet: $<$ <ttp://www.zdnet.com/pcweek/>.

BROWN, A. D. Narrative, politics and legitimacy in an IT implementation. Journal of Management Studies, v. 35, n. 1, p. 35-58, Jan. 1998.

CALDAS, M. P. Toward a more comprehensive model of managerial innovation diffusion: why consultants are not the only ones to blame. Paper presented at the Managerial Consultation Division during the Annual Meetings of the Academy of Management. Cincinnati, $\mathrm{OH}$ : Academy o Management, 1996.
CALDAS, M. P., WOOD JR., T. Inovações gerenciais em ambientes turbulentos. In: WOOD JR., T. (Ed.). Mudança organizacional: aprofundando temas atuais em administração de empresas. São Paulo : Atlas, 1995.

CALDAS, M. P., WOOD JR., T. "For the English to see": the importation of managerial technology in late $20^{\text {th }}$ century Brazil. Organization, v. 4, n. 4, p. 517-534, Nov. 1997.

CARVALHO, L. R. M. Integrated systems implementation. In SIMPOI, 1., 1998, São Paulo. Anais... São Paulo : EAESP/FGV, 1998. p. $273-287$.

CORREA, H. L. ERPs: por que as implantações são tão caras e raramente dão certo? In: SIMPOI, 1., 1998, São Paulo. Anais.. São Paulo : EAESP/FGV, 1998. p. 288-300.

DAVENPORT, T. H. Putting the enterprise into the enterprise system. Harvard Business Review, v. 76, n. 4, p. 121-131, July/Aug. 1998.

DIMAGGI0, P. J., POWELL, W. W. The iron cage revisited institutional isomorphism and collective rationality in organizational fields. American Sociological Review, v. 48, n. 1 , p. 147-160, 1983

FROST, P. J., EGRI, C. P. The political process of innovation. In: STAW e CUMMINGS (Eds). Research in organizational behavior. Greenwich : JAl Press, 1991. v. 13.
GILL, J., WHITTLE, S. Management by panacea: accounting for transience. Journal of Management Studies, v. 30, n. 2, p. 281-295, Mar. 1992

LAMPEL, J. Innovation as spectacle: dramaturgical construction of technological change. Paper presented at Conference on the Social Construction of Industries and Markets. Chicago, 1995.

MCGEE, J., PYBURN, L., PRUZAK, L. Managing information strategically. New York : John Wiley \& Sons, 1993.

MEYER, J. W. ROWAN, B Institutional organizations: forma structure as myth and ceremony. American Journal of Sociology, v. 83, n. 2, p. 340-363, Sept. 1977.

MINTZBERG, H. Structure in fives: designing effective organizations. Englewood Cliff, NJ : Prentice-Hall, 1983.

SAP, o espírito do Vale do Silício chega ao Reno. Gazeta Mercantil, São Paulo,17 nov. 1998. C6-C7. Tradução da Business Week.

SCOTT, W. R. The adolescence of institutional theory. Administrative Science Quarterly, v. 32, n. 4, p. 493-511, Dec. 1987.
This article was originated from two research grants from Núcleo de Pesquisas e Publicações (NPP), the research institute from EAESP/FGV. The complete reports were titled: "Modas e modismos gerenciais: o caso dos Sistemas
Integrados de Gestão" (NPP Report \# 16/99, in Portuguese and "Fads and fashions in management: an empirical study on Enterprise Resource Planning Systems (ERP) in Brazil”.
A preliminary version (in Portuguese) of this research consolidation paper was presented at the 1999 ENANPAD (OLS Division), as well as at the 1999 Annual Meetings of the Academy of Management (MC Division). 